\title{
[ 119$]$
}

\section{Remarks on the Military Hiflory of Briftol in the Seventeenth Century, with a Sketch of the Outworks, by Edmund Turnor, Efq. F. R.S. and F. S. A.}

\author{
Read June II and 18, 1801.
}

WE great importance of Briftol, as the fecond city in the 1 kingdom,-its fituation commanding at once the rich county of Somerfet, and the chief entrance into $W$ ales, rendered the conqueft of it of the utmoft confequence to both king and parliament, whofe fpirits, during their unhappy contefts, were alternately elated or depreffed as either party fucceeded in the fiege, or failed in the defence of the town. But the great extenfion of commerce, and the confequent increafe of population, have fo much enlarged the circuit of Briftol, that what was only an inconfiderable fuburb in the time of Charles the firft, is now become a new town, extending over, and in a great meafure defacing, the lines of fortification which formed the outworks of the city. An attempt, however, to preferve fome idea of the remaining military veftiges, as exhibited by letters patent under the great feal of England, and fign manual of CHARLES THE First, conferring the office of treafurer of the garrifon on an anceftor of the author of this communication, may not be foreign to the views of the Society.

The pofition of the original town was well chofen for ftrength and fecurity, being built on an eminence rifing on both fides from the rivers Avon and Frome, thus guarded by nature againft hoftilities, whilf it was acceffible on every fide to the benefits of commercial intercourfe. The cafte contained within its walls 
an area of three acres, and defended the eaftern part of the town. The fortifications were very ancient, and are thus defcribed by Leland. "There be in fome parts of the town double walls, a " token that it hath been augmented. Five inner gates of " the old town, four in the outer walls, and two beyond the " bridge. In the caftle be two courts; in the outer is a great " dungeon tower, made, as it is faid, of ftone brought out of "Caen in Normandy, by the red earl of Gloucefter. A pretty " church and much lodging in the fecond area: many towers yet " Ptanding in both courts; but all tendith to ruin [a]." Towards the clofe of the year 1642 , when the civil commotions had affumed a formidable afpect, this fortrefs and walls were repaired; and for further defence, the fort on Brandon hill, and that on St. Michacl's hill, afterwards called the Royal Fort, were formed with lines of communication.

Whatever might have been the political bias of the place, the furrendering it into the hands of the Parliament is attributed to the intrigue of two ladies, who found means to open the gates to Col. Thomas Effex, on the $5^{\text {th }}$ of December 1642; but fcarce had two months elapfed before Col. Nathaniel Fiennes was appointed to fucceed him. The conduct of this governor, and the execution of Yeomers and Bouchier, who were hanged for holding a correfpondence with the King's friends, fo cxafperated the inhabitants, that the King's army, profiting by the general difcontent, were encouraged to lay fiege to the town on the $24^{\text {th }}$ of July 1643 , and a plan was concerted to feize the fhipping in the harbour, which was effected on the fame day. Although in the attack on the Somerfethire fide, led on by the Marquis of Hartford and Prince Maurice, fome of the affailants mounted the wall, yet, by the vigorous defence from within, they were driven back

[a] Leland's Itin. VIJ. 68:

with 
with a Sketch of the Outworks.

with great naughter; but on the Gloucefterhire fide, where Prince Rupert commanded, Colonel Warhington, finding a weak place in the curtain, between Brandon Hill and Windmill Forts, out of the reach of cannon, entered, and made room for the horfe to follow. Thus Prince Rupert preffed forward to Froom Gate, but with the lofs of many officers and men, who were thot from the windows. An arrival fo unexpected furprifed the governor into an immediate capitulation. Clarendon fays, "There were in the town 2500 "foot, and a regiment of horfe and dragoons. The line about the " town was finifhed, yet in: fome places the graff was wider and " deeper than in others. The caftle was very well prepared, and " fupplied with great ftore of provifions to endure a fiege [b]."

After public thankfgiving at Oxford for this great victory, the King went with Prince Charles and the Duke of York to fix Prince Rupert in the government of Briftol [c], and foon afterwards Letters Patent paffed the great feal, appointing the military eftablifhment there in the following words $[d]$.

"Charles, by the grace of God, King of England, Scotland, France, and Ireland, Defender of the Faith, \&c. To our truftie and welbeloved s̃vant Edmond Turnor, Efq. thẽ rer of our garrifons of Briftoll, Bathe, the Towne and Caftle of Berkeley, Nunney Caftle, Farley Caftle, and Portfhall Pointe, lying and being within our feverall counties of Somfett, Gloucefter, and the citie and countie of Briftoll. Whereas for the good and fafetie of our people, we have thought fitt to place and fettle fevall garrifons in

[b] Hift. Rebellion, I1. 295.

[c] Charles I. lodged in the houfe of Mr. Crefwell, in Small Street, which is ftill remaining, and exhibits a variety of beautiful gothic architecture.

[d] From the Letters Patent under the great feal, penes Edm. Turnor.

VoL. XIV.

R 


\section{I22 Remurks on the Military Hifory of Briftol,}

our cities of Briftoll and Bathe, the Towne and Caftle of Berkeley, Nunney Caftle, Farley Caftle, and Porthall Point, and for the well ordering, fortifying, manneing, and maynteyning of the faid fererall garrifons, have thought it likewife fitt, by the advice of our Councell, to caufe an eftablifhm ${ }^{\mathrm{t}}$ of contribuicon to be made, fettled, affigned, and fett out, to and for the maynetenance of the garrifons aforefaid, and the officers and foldiers there. As ALso an citablifhm of a conftant pay and allowances to be made, iffued forth, and allowed weekly to fuch troopes and regim ${ }^{\text {ts }}$ of horfe and foote, and the fevall officers and fouldiers of the fame, and for divers other ends and p̃pofes tending to our s̃vice, the maynetenance and fafetie of our faid garrifons in fuch forte as by one fchedule figned with our figne manuall, bearing the fame date with theis prents hereunto annexed, doth and may appeare. AND WEE doe further order and affigne two hundred pounds by the weeke to be duely and conftantly paid out of fuch moneys as thall arife and become due out of the cuftomes, by the hand of the officer or officers of our cuiftomes, for the ufe and better mayntenance of our faid garrifons. Now, to the end our good intencons for the fafetie of our garrifons aforefaid, and all our loving fubjects there, may have a good effect, by a due execucon of the faid eftablifhm ${ }^{t}$ in all the partes thereof, as is intended by us, WEE repofeing efpi all truft and confidence in your abillitie, integritie, and good inclinacon to our faid svice, have ordained, conftituted, and appointed, and doe by thefe prents ordaine, conftitute, and appointe you, the faid Edmond Turnor, to be our Threr for our faid garrifons of Briftoll, Bathe, the Towne and Caftle of Berkeley, Nunney Caftle, Farley Caftle, and Porthall Pointe, giving you hereby full power to acte and $\mathrm{p}^{2}$ forme whatfoever unto the place of Trer of our faid garrifons doth and may in any forte belong and appiteyne. And you, the faid Edmond Turnor, are to comence and begine to be Trer of our garrifons aforefaid, for the receiving, collecting, and iffueing 
with a Sketch of the Qutwarks.

forth all the faid fevall fomes of maney from the firf of November laft part. And the better to enable you, the faid Edmond Turnor for the pformance of our s.vice aforefaid, W,EE do hereby will and require all our theriffes, commiffioncrs, juftices of peace, maiors, bayliffes, high conftables, and petit conftables, and all other our officers, minifters, and other our loveinge fubjects whatfocver, in our feverali counties of Somfett, Wiltes, and Gloucefter, and our citie and countie of Briftoll, to be aidinge and affifting to you, your fufficient deputies, collectors, or affignes, and every of you, in receiving, leavying, collecting, and gathering the contribur cons of the feverall and refpective hundreds, cities, townes, villages, and places meñconed in the faid fchedule hereunto annexed. AND WEE doe hereby further comand that all high conftables, and petit conftabies, and all other prons whatfoever whome thefe may concerne, doe yield obedience and forthwith execute all fuch warrants as they, or any of them, thall from tyme to tyme receive from you the faid Edmond Turnor, as Tr̃er of our faid garrifons, or any of your deputies, collectors, or affignes, authorized by you, touching or concerning the leavying and receiving all fuch fories of money as thall arife and growe due by way of contribucon, which fomes of money foe leavied and received by them, they, the faid high conftables, petit conftables, and all others whatfoever whorne it concerned as aforefaid, are to bring in and convey to fuch places and to fuch prons and att fuch tymes as you, the faid Edmond Turnor, your deputies, collectors, or affignes, fhall appointe and direct, and hereof they nor any of them may att any tyme faile, under fuch paine and penaltie as thall be inflicted uppon them by a councell of warre; and for defaulte of paym ${ }^{t}$ of the aforefaid contribuicon, wee doe alfo hereby require and coniand all our officers and fouldiers within or belonging to our faid garrifons, from tyme to tyme to give their beft affiftance in fending forth fuch parties of horfe or foote as you thall think fitt and neceffary for the due leavying 
and collecting of the contribuicons aforefaid. AND you, the faid Edmond Turnor, are from tyme to tyme to iffue forth and pay out of all and every fuch fome or fomes of money as thall be raifed and leavied, as well out of the contribuicons as the cuftomes aforefaid, to fuch p fons, and according to the order and forme for the paym $^{t}$ of the faid fevall garrifons expreffed and fett forth in the faid eftablifhm ${ }^{t}$ hereunto annexed. And you are hereby alfoe required to demeane and behave yourfelfe in the faid place of $T \dot{\tilde{r}}$ er, and to pforme and execute fuch orders and inftrucicons as you Thall receive from us, bearing the fame date with theis pfents, and all fuch further orders and inftručcons as you thall from tyme to tyme receive from us. AND for the execũ con of our faid fervice, wee doe give, grant, and allowe to you, the faid Edmond Turnor, thirteene fhilling four pence p. diem, to you for your two deputies, to each five fhilling p. diem, to you for two clerks, to each two fhilling fix pence p. diem, to you for eight collectors of the contribũ cons, to each four fhilling p. diem, to three keepers of the ftores or magazines for provifions and victualls, to each three thillings and foure pence p. diem. And likewife wee doe hereby give allowance for books, bagg, paper, inke, pens, and all fuch other neceffaries as our faid fervice thall require; all which faid feverall allowances thall be allowed unto you uppon your accompt; and for foe doeing this thall be your fufficient warrant. IN WITNES whereof wee have caufed theis our lĩes to made patent. Witnes ourfelfe att Oxford, the fourth day of December, in the twentieth yeare of our Raigne [e], p. ip̃m Regem."

\section{WILLYS.}

[e] On the 1oth of February in the fame year, Edmund Turnor, Efq. was appointed captain of a troop of cuiraffers, to bring in contributions to the garrifon of Briftol. At the battle of Worcefter he was taken prifoner; and was knighted foon after the reftoration. He died 1707 , aged 88 , and was buried at Stoke Rochford in Lincolnhire, the place of his refidence.

"Charles 


\section{“Charles $R$.}

An Establishment for Briftoll, comprifinge Bath, Berkeley Caftle, Portfhall Pointe, Nunny and Farley Caftles dependent thereof. to comience and beginne the firft of November 1644 .

\section{Three Regiments of Foote, I 200 in each Regiment, officers and all, each Regiment to bee paid accordinge to theife. enfuinge partic $]_{\text {rs, }}$ viz:}

\section{Per Weeke.}

To a Colonell .......... 050000

To a Lieuteñnt Colonell. . . $04{ }_{4}{ }_{3} 0_{4}$

To a Sarjeant Major....... 0316 o8

To a Captaine.......... 02 10 00

To a Lieuteñnt ......... OI 08 o0

To an Enfigne.......... 00 18 oง

To a Gentleman of Armes.. 000800

To a Corporall.......... 00 0500

To a Drúme Major....... 0008 oo

To a Drumer.......... 000500

To a Quartermafter....... O. 00 o0

To a Chaplaine.......... or 00 oo

To a Provoft Marfhall ..... or co oo

To.a Chirurgeon......... 020000

To a Carriage maiter...... 00 I 800

To a comon Souldier....... 0003 c6

After which rate three regi-

ments of foote theire pay.

amounteth. weekely to...833 I7 00 .

A regiment of feaven troopes of horfe, confiftinge of 60 horfe to each tronpe, officers and all, and his Highnes troope of horfe, confifting of 200 befides. officers, to bee paid according to theile enfuinge particl rs.

To a Colonell........... 07 0000

To a Lieutañnt Colonell... 06 oo 00

To a Serjeant Major....... 05 10 00

To a Captaine........... 05 00 00

To a Lieuteñnt ......... 03 0000

To a Coronet .......... 02 0500

To a Quartermafter ....... O I I0 00

To a Corporall........... or or oo

To a Trumpeter......... 00 I7 06

To a Chirurgeon ....... . 001706

To a Chaplaine ......... or 03 oc

To a Trooper............ 00 I0 00

After which rate one regiment of horfe theire pay amounteth weekely to........3 352 02:00

His Highnes troope of horfe, theire pay weekely ...... I 20 I7 00

The chiefe officers of the fevall garrifonis to bee paid weekely as followeth, vir.

The Governour, the Treafurer to fupply his charges. 
The Lieuteñnt Governour . 2 I 0000 The Deputy Governour.... 100000 The Major............ 05 0000 The Comiffary Genall or

Mufter Mafter......... 03 1000 The Quartermafter Genall. . 1020608 The Engineir .......... 020608 The Petardier or Engineir for

Fireworks ......... 050000 The Provof marthall...... 0206.08 The Keeper of the Stores .... OI 00.00 The Proviant Mr........ or 00 oo The Governour of Bathe ... o7 00 oo The Governour of Berkeley. 070000 The Governour of Porthall

Pointe............ 050000
The Governour of Nunny

Caftle ............. 050000

The Governour of Fandey.

Caftle ............. 050000

The Treafurer ........... Q4 ${ }_{3} 04$

To him,for Eight Colledors is 04 ,os

To.him for Two Deputyes. . 03 10 os

To him for Two Clarkes... or 1500

To him for Three Keepers of the Magazine of Victualls o3 io $\infty$

To the Gunners and other inferiour officers as followeth, viz.

Malter Gunner.......... 020608
Waterfort, Ordinance

7.

Brandon Hill Fort, Ordinance

6.

Greate Forte,

Ordinance

22.

Redoute, Ordinance

7.

Prior Hill,

Ordinance

I 3.

Lafford Gate,

Ordinance

7 .
John Greenfield, $M^{r}$ Gunner ..... . .

Richard Abbot, Mate .......... o 14.00

To Three Gunners, each rob........ or 10.00

Francis Pitt, Mr.Gunner ........... . I.7

Hen. Goffe, Mate ........... 00 if 00

To Two Gunners, each $10^{\text {sh }} \ldots . .$. or 00 oo

John Skinner, $M^{r}$ Gunner ........ co, 17, 06

John Sherland, Mate .......... oo I4;

To Six Gunners, each $10^{\text {sh }} \ldots \ldots \ldots$ :... 03 . 00 .00

Comiffary of Vidualls.......... or . 10 o

Walter Daniell, $M^{r}$ Gunner ......

John Gilburte, Mate ............ oo I4 00

To Two' Gunners, each $10^{\text {sh }} \ldots .$. or 00 oo

Jof́eph Tucker, Mr Gunner ...... $00 \quad 17 \quad 06$

Willm Howlett, Mate.......... oo I4 00

To Three Gunners, each $10^{\text {sh }} \ldots .$. or io 00

John Simonds, $\mathrm{M}^{\mathrm{r}}$ Gunner ......

John Jones, Mate. ............ 00 ' 1400

To Sixe Gunpers, each $10^{\text {sh }} \ldots \ldots . .030000$

Temple, 
Temple,

Ordinance

I4.

Redcliffe,

Ordinance

15.

Caftle and Neivgate,

Ordinance

I6.

Froome Gate, and

Pithay Gate,

Ordinance

2.
James Fuller, Mr Gunner ........ co 1706

John Scott, Mate.............. o o I4 00

To Five Gunners, each $10^{\text {sh }} \ldots . . .02$ 10 00

John Sterrey, Mr Gunner ........ oo 17 o6

Richard Hamans, Mate........... oo 1400

To Four Gunners, each $10^{\text {sh }} \ldots \ldots . .020000$

John Robert, Mr Gunner ........ oo I7 06

John Warden, Mate........... 001400

To Eleaven Gunners, each $10^{\text {sh }} \ldots$ o5 10 o0

Comiffary of Victualls .......... or Io 00

William Purfer............... o o I4 00

William Crookebank........... o o I4 00
For makinge of Armes and Ammun ${ }^{2}$ con ................. $35^{\circ}$

For finilhinge the Workes...... 2 I9

Which is to be raifed upon the Affignãcons following, viz.

Out of the Hundreds of Som ${ }^{2}$ et hereunto annexed, rated weekly att may yield ......

Out of the Hundreds of Wil'tes hereunto annexed, rated weekly. att . may yield ..... 500

Out of the Hundred of Gloucefter, being the whole Divifion of Berkeley, rated weekly at

but may yield ..........

Out of Briftol, hereunto annexed, rated weekly at ........... I5

Out of the Cuftomes........ 200

300
The Hundreds of Somets, beinge the Eaft Divifion to bee eftablifhed for the feverall garrifons aforefaid.

Bartcliffe cum Bedminiter Portbury

Brent cum Wreinton

Bempiton

Winterftoke

12 hides cum Glafton.

Welsford cum Burgo

Whitfon

Chew

Chewton

Keynefham

Bathford cum Burgo

Hainxton cum Claverton

Wilbey cum libitate Hofethorne

Froome cum lib tat

Almerfdon cum librtat

Catfarh

Norton Ferryes

Brewton cum Burgo 
I. Re Remarks on the Military Hiftory of Briftol,

The Hundreds of Gloucefter, beinge the whole Divifion of Berkeley, to be eftablifhed for the garrifons aforefaid.

Berkeley Hundred

Crumbaldafh Hundred
Langley cum Swinhed Hundred

Thornebury Hundred

Henbury Hundred

Puckle Church Hundred

Barton R̃s Hundred."

BY this eftablifhment the treafurer had full power to demand fuch force as he might judge neceffary to compel the payment of contribution to the garrifon, fubject only to his Majefty's directions: thus the commiffion was held independent of any intermediate authority.

The fums which were payable in each county appear already in the fchedule; the only particulars which the author of this communication is poffeffed of, are as follows.

"Hundred of Radcliffe $[f]$ cum Bedminfter payeth $\oint_{0} .200$ per

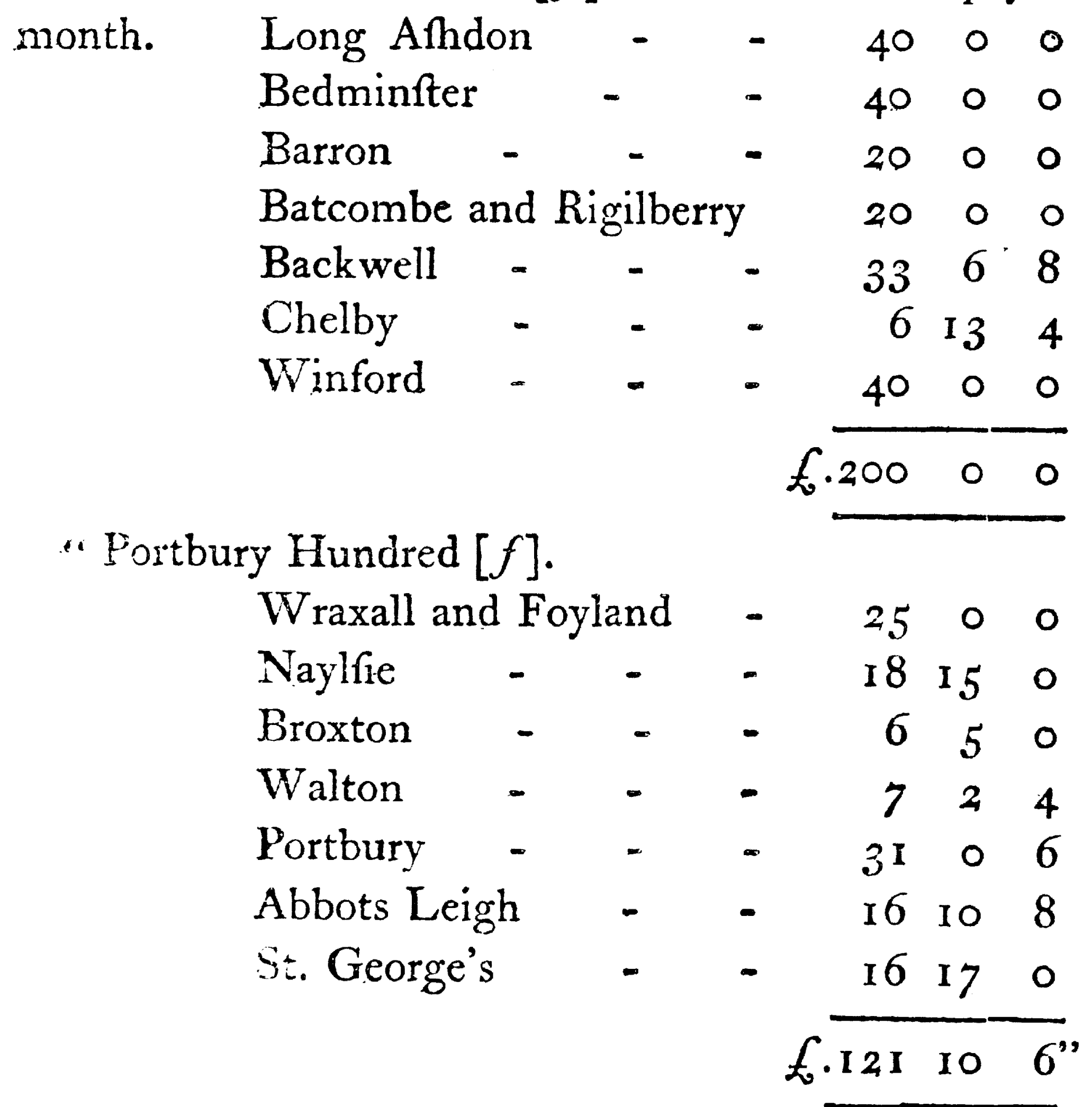

[f] MS. penes Edm. Turnor. 
It does not appear from the annals of Briftol, that any thing particular occurred there during, the government of Prince Rupert, which lafted little more than two years; for, in Septernber i 645 , the parliament army, under the command of Fairfax, approached the city. Col. Weldon fat down with his brigade at Pile Hill (near Pile Street) within mufket-fhot of the walls on the fouth fide. Fairfax took his quarters at Stapleton, on the north. Lawford's Gate, where there was a double work, was taken poffeffion of by Colonels Mountague and Pickering; who, being feconded by Major Defborough's horfe, advanced to the city walls, where they became mafters of the gate againft the caftle. Sir Hardrefs Waller, with his and Fairfax's regiments, entered between Lawford's Gate and the Avon; and joined the reft of the brigade. Prior's hill fort, being exceeding high, was attacked with great difadvantage by Colonel Rainfborough, who fought near three hours, but could not enter, until Col. Hammond, with Major-General Skippon's regiment, having forced the line towards the Froom, came up withinfide the works, and ftormed Prior's hill fort on the part which was inward; by which means they took poffeffion of that fort. Thus the line from Prior's hill fort to the. Avon was in the poffeffion of the affailants [g]. The Royal fort, which had the reputation of frength, lay open to Brandon hill fort, which, if taken, would, from its height; have commanded the whole plain within the Royal fort; added to which there was a total deprivation of water. Thefe confiderations, together with the raging of the plague in the city; which had reduced the eftablifhment from 3600 to 2800 effective men, and a fcanty provifion of powder in the magazines, induced Prince Rupert, contrary to all expectation, to furrender the city to Fairfax $[h]$. The king, buoyed up by the fulleft af-

[g] Sprigge's Anglia Rediviva, p. II 3 .

[b] Prince Rupert's declaration and narrative, as quoted by Barret.

Vol. XIV. 
furance from the Prince, that he could defend the place four months, was forming fchemes and collecting forces for its relief, when the fatal news arrived. Full of indignation, his Majefty revoked all Prince Rupert's commiffions, and directed him to leave the kingdom!

Defcription of the Sketch of the Outworks[i], accompanying this Paper.

The Outworks, beginning from the Water fort abovie the Glarshoufe in Limekiln Lane, are plainly difcernible up to Brandon hill fort, and thence to the fouth-eaft corner of Berkley Square. From thence the line continued by the weft end of Park Street (the precife fpot where Wanhington made his breach) to the Royal fort, now the feat of Thomas Tindale, Efq. From thence to Mr. Carden's garden, near the Mountague tavern, where remains of the redout, or Colfton's fort, are yet vifible; and fo on to Prior's hill fort, near the north ends of St. James's Place, and Somerfet Street; then by Stoke's'Croft gate acrofs the river Froom to Lawford's gate, and fo to the Avon oppofite Tower Harratz, from whence the wall is vifible by Temple and Redcliffe gates to the Avon again. Prince Rupert ftates this line to have been four miles in circumference, the graff not exceeding feven feet wide, nor five feet deep. The works from Prior's hill fort to Lawford's gate, not five feet high ; and the higheft work of the Royal fort not quite twelve feet [k]. The city, within the walls, is diftinguinhed by being thaded; and the gates. and forts, with the number of ordnance provided by the eftablinment, are fpecified in the plan. The new town extends beyond the line of the outworks, and thofe ftreets only are defcribed which interfect that line.

[i] Pl. XXXIV, [k] Declaration and narrative, ut fupra. 


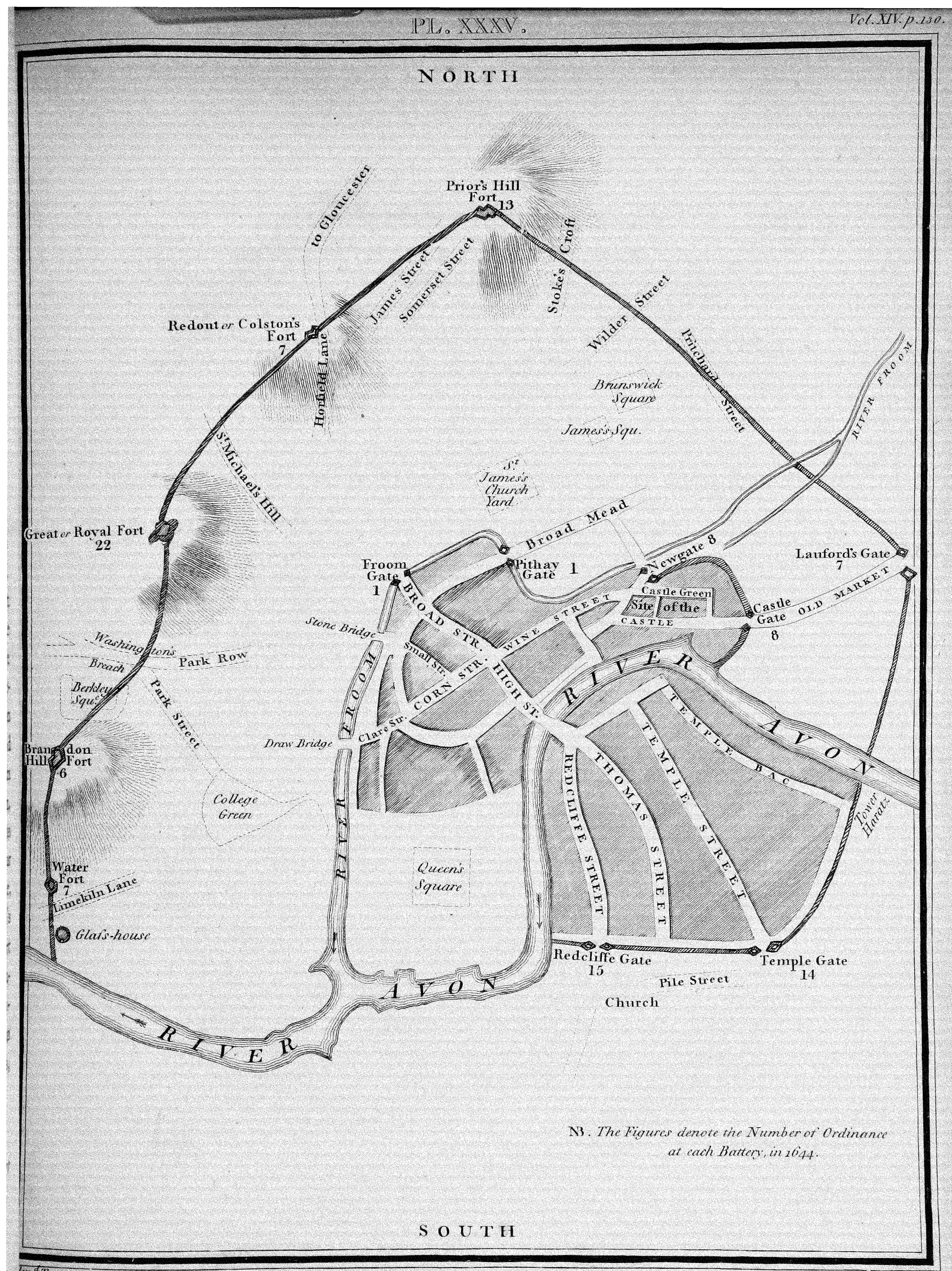


Short notices reppecting the Garrifons fubordinate to Briftol in 1644 .

BAтH was garrifoned in the early part of the civil wars for Charles I. and joool. was expended on its fortifications; but it foon became one of the principal pofts of the parliamentary forces. Sir William Waller lay here a confiderable time with his whole army: but after the battle of Roundway down in I 643 , the king's troops retook poffeffion of this garrifon without difficulty. 'It was then included in the Briftol eftablifhment; but was given up by Sir Thomas Brydges in July 1643 , , previous to the furrender of Briftol [l].

Berkley Town and Caftle in Gloucefterhire, the chief ftrength of which confifted in the outworks and church, was delivered up to the parliamentary forces by the gallant Sir Charles Lucas, the $25^{\text {th }}$ of September 1645 , after a vigorous defence of nine days [ $m$ ].

Nunney Caftle, three miles S.W. of Froom in Somerfethire, had in it a large magazine; but was taken by the parliamentary army after a fiege of two days, and burnt, to prevent the poffibility of its future fervice to the king, Sept. 8, $645[n]$.

Farley Caftle, Somerfethire, furrendered to the parliamentary army, Sept. 15, $1645[0]$.

Porthall, or Porthead Point; in Somerfetfhire, a fortification commanding the King's road in, the Briftol Channel, furrendered to the parliamentary army on the 28 th of Auguft $\mathrm{r} 645$; after fix days refiftance; and thus the communication with the chamrel, by water, was cut off, previous to the fiege of Briftol.

[l] Collinfon's Somerfethire, I. 30 . [n] Collinfon; 11.227. [m] Anglia Rediviva, ut fupra.

[0] Anglia Rediviva, ut fupra. 